\title{
テーパ型超音速複葉翼の始動特性と翼端板効果*1
}

\section{Aerodynamic Characteristics and Effects of Winglets of the Boomless Tapered Supersonic Biplane during the Starting Process}

\author{
藤 園 崇*2 - 山 下 博*2 - 豊 田 篤*2 永 井大 樹*3 \\ Takashi Fujisono, Hiroshi Yamashita, Atsushi Toyoda, Hiroki NagAi, \\ 浅 井 圭 介*3 . 鄭 信 圭*2 . 大 林 茂*2 \\ Keisuke AsAi, Shinkyu JEONG and Shigeru OBAYAshi
}

Key Words : Supersonic Biplane, Pressure-Sensitive Paint, Computational Fluid Dynamics, 3D Printer

\begin{abstract}
The aerodynamic characteristics and the effects of winglets of a tapered supersonic biplane during the starting process have been investigated through Experimental and Computational Fluid Dynamics (EFD/CFD). Three types of the tapered biplane model were used: without winglet (type-N); with the winglet which covers only the aft-half of the wing tip (type-A); with the winglet which covers the entire wing tip (type-B). Experiment was conducted in the supersonic blow-down wind tunnel with $600 \mathrm{~mm} \times 600 \mathrm{~mm}$ cross section located at the High-speed Wind Tunnel Facility of Institute of Space and Astronautical Science, JAXA. The flow conditions covered from $M_{\infty}=1.5$ to 1.9 with increments of 0.1. Pressure-Sensitive Paint was applied to measure pressure distributions on the surface of supersonic biplane models. CFD simulations were conducted to compare with experiment and to investigate effects of the Mach numbers in detail. The tapered biplane without the winglet was found to start between $M_{\infty}=1.8$ and 1.9. The difference of the starting Mach numbers between type-N and type-A was small. On the other hand, the starting Mach number of type-B was about 0.05 higher than that of type-N.
\end{abstract}

\section{1. 研 究 背 景}

次世代超音速旅客機を開発する際に問題となるのが，ソ ニックブーム騒音や多大な造波抵抗に伴う燃費性能の低さ である。これらの問題を解決する手段の一つとして, Adolf Busemann によって提案された複葉翼1) を用いた, 超音速 複葉翼理論 2,3$)$ が近年注目されている. 超音速複葉翼は, 互 いに向き合う二つの三角形からなる翼形で, 超音速飛行時 に一方の三角形の前縁から発生する圧縮波がもう一方の三 角形の頂点から発生する膨張波と干渉し，互いに波を打ち 消し合う。この波の相殺効果によって体積に依存する造波 抵抗を低減可能であるため, 低ブーム・低抵抗な超音速旅 客機を実現させる一つの手段として期待されている.

超音速複葉翼を実飛行に適用させるには, 複葉翼特有の 始動・不始動問題を克服する必要がある4,5). 第 1 困は設計 マッハ数 $M_{\infty}=1.7$ 付近の複葉翼周りの衝撃波の様子を示 す.第 1 図より超音速複葉翼は加速時には翼の前縁に離脱 衝撃波が発生し, 不始動状態（第 1 図 (a)）と呼ばれる抵抗 の非常に大きな状態となる。一方, 前縁に発生した衝撃波 が翼間に吸い込まれ, 始動状態（第 1 図 (b)) となると, 翼 間で圧縮波が干渉され抵抗值が小さくなる．この始動状態

\footnotetext{
*1 (C) 2012 日本航空宇宙学会

平成 21 年 12 月 11 日, 平成 21 年度宇宙航行の力学シンポジウ 厶講演会において発表. 平成 22 年 9 月 24 日原稿受付

*2 東北大学流体科学研究所

$* 3$ 東北大学大学院工学研究科
}

と不始動状態の移行時には抵抗值が不連続となり, またヒ ステリシス現象の存在も確認されている ${ }^{5,6)}$. 加えて, 過去 の研究から 2 次元複葉翼型と同翼型で構成される 3 次元複 葉翼 (矩形翼) では, 不始動状態から始動状態へ移行する マッハ数 (始動マッハ数) が異なることが知られている7,8). これは有限翼である矩形翼の翼端からの流れ出しの影響で あることが報告されている9).

近年ではより現実的な複葉翼形状の検討が進められてお $り$, 単純な矩形翼に比べてテーパ型複葉翼の空力性能が優 れていることが CFD 解析から明らかにされている10). ま たテーパ翼の空力性能をさらに向上させる研究も実施され ている. 加えて構造設計や空力性能の観点から翼端板の設 置も検討されている. 過去の研究から, 三次元複葉翼（矩 形翼）では翼端で理想的な衝撃波干渉がくずれ，零迎角時 において抵抗が増加することが示された ${ }^{11,12)}$. 抵抗増加を 抑え，設計点で低ブーム・低抵抗を実現するためには翼端 における流れの 3 次元性を小さく抑えることが有効である. このため翼端板の設置が検討されている。しかし，テーパ 型複葉翼の始動特性や翼端板がこれらの特性に与える影響 については，詳細な調査は行われておらず，これらに関す る知見を深める必要がある。

本研究では実験と計算の両手法を併用して, テーパ型超 音速複葉翼の始動特性を明らかにする。また翼端板がテー パ型複葉翼の始動特性および空力特性に及ぼす影響を調べ る. 具体的にはテーパ型超音速複葉翼の風洞実験模型を設計 


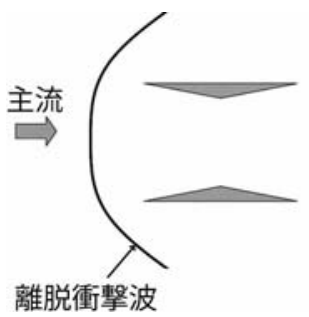

(a) 不始動状態

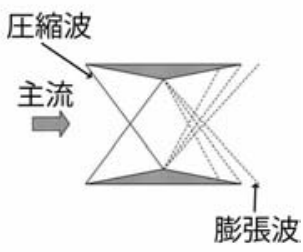

(b) 始動状態

第 1 図＼cjkstart設計点付近における複葉翼周りの衝撃波の様子

L, 宇宙航空研究開発機構宇宙科学研究所 (ISAS/JAXA) に押いて風洞実験を行う。本実験では感圧塗料（PressureSensitive Paint, PSP) 計測技術13,14) を用いて, 設計マッ 八数 1.7 近傍の翼表面圧力分布を計測する。また実験では 計測困難な詳細なマッ八数において CFD 解析を実施し，始 動特性と空力特性に翼端板が及ぼす影響を考察して議論を 深める.

\section{2. 風洞実験手法}

2.1 風洞 風洞実験は ISAS/JAXA が所有する高速気 流総合実験設備（間欠式超音速風洞）を利用した。第 2 図 に当該風洞の概観を示し，第 3 図に風洞模型の取り付けの 様子を示す。また第 1 表に当該風洞の諸元を示す.

2.2 実験模型 第 4 図は本実験模型の概観を示す。実 験模型は円盤部・支持部・スティングから構成され，材質 はいずれもSUS304 とした. 円盤部は対称面を模擬してお り, テーパ型複葉翼の半裁模型の翼根側を円盤部に取り付 けた。 円盤には円盤裏側から翼間圧力分布を計測するため 空を設置した。このように円盤部に翼の半裁模型を設置し て空を設けることで，翼幅方向へ翼間距離が狭まるテーパ 型複葉翼の互いに向かい合う翼表面に十分な励起光を確保 でき, PSP 圧力計測が可能となる. また当初ガラス空（材 質 BK7）を利用する予定であったがテストラン中に破損し たため本 PSP 計測ではアクリル空を利用した。

第 5 図は本模型のテーパ型翼部分（材質 SUS304）の拡 大図を示す。テーパ比は 0.4 , アスペクト比は 4.0 とした. 本模型は製作上の都合で翼の前縁と後縁にそれぞれ $0.2 \mathrm{~mm}$ の厚みをもたせた。これに合わせて CFD 解析では厚みを もたせた本模型の 3 次元非粘性計算を実施し, 設計マッハ 数 $M_{\infty}=1.7$ において理想的な衝撃波干渉が達成されるよ う翼間距離を修正した。両翼の外側には, 翼間の衝撃波干 渉に影響しないように補強用の厚みをもたせた。また複葉 翼下翼の翼幅方向 $50 \%$ 位置には, 静圧孔を翼弦方向 $25 \%$ と $75 \%$ 位置に二つ設けた。

本翼模型については，模型取り付け時に翼間距離が設計 值より狭くなっていたことをノギス計測にて確認した。具 体的には，第 5 図中に示すように翼根部の翼間距離は設計 值の $20.2 \mathrm{~mm}$ から $20.03 \mathrm{~mm}$ へと変わり, 翼端部の翼間距 離は設計值の $8.08 \mathrm{~mm}$ から $7.68 \mathrm{~mm}$ へと変わった。

翼端板模型については 3D プリンタ (ZPrinter650, ZCORPORATION) 15) を用いて形状を検討した。本実験

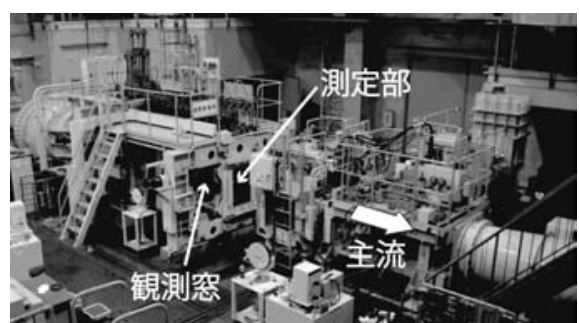

第 2 図 ISAS/JAXA 高速気流総合設備概観（間欠式超音速風洞）

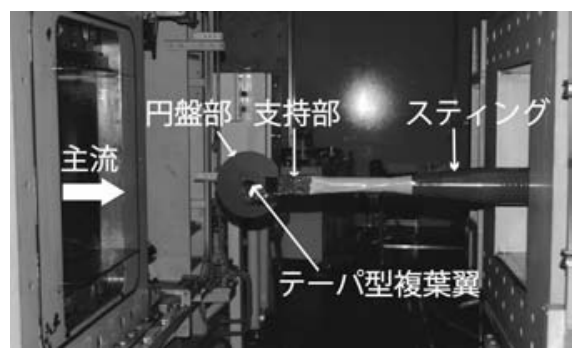

第 3 図 風洞模型取り付けの様子

第 1 表 ISAS/JAXA 高速気流総合実験設備：超音速風洞諸元

\begin{tabular}{lc}
\hline \multicolumn{1}{c}{ 形 式 } & 間欠吹き下万し式 \\
\hline 測定部断面 & $600(\mathrm{~W}) \mathrm{mm} \times 600(\mathrm{H}) \mathrm{mm}$ \\
マッハ数 & $1.5 \sim 4.0$ \\
測定時間 & 30 秒以上 \\
総温 & 常温 \\
総压 & $149.1 \mathrm{kPa}$ 以上 \\
作動流体 & 乾燥空気 \\
\hline
\end{tabular}

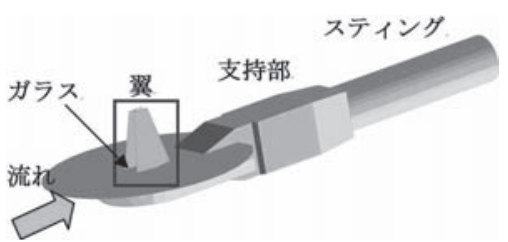

(a) 翼側

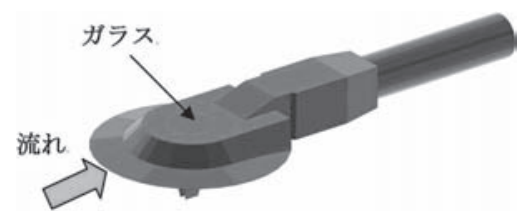

(b) 裏側

第 4 図 風洞実験模型の概観

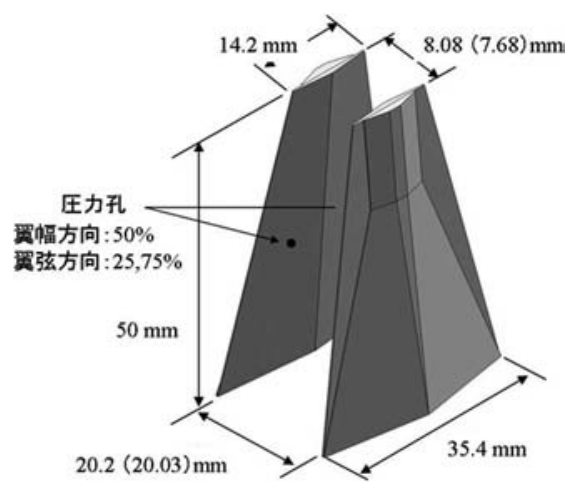

第 5 図 風洞実験模型のテーパ型翼部分拡大図 


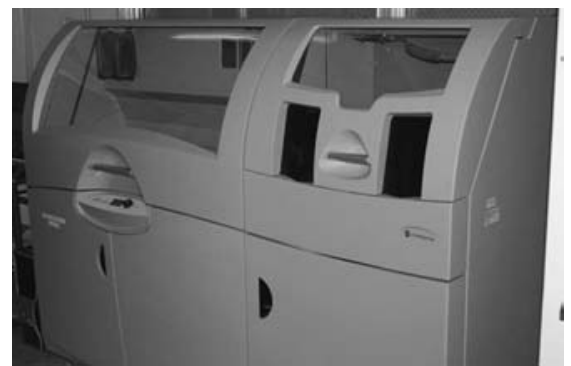

第 6 図 $3 \mathrm{D}$ プリンタ外観

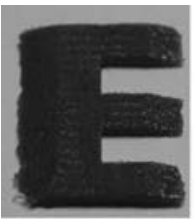

(a) type-N

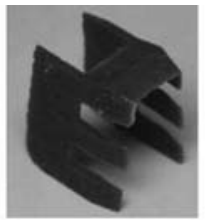

(b) type-A

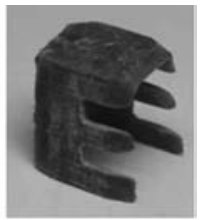

(c) type-B
第 7 図 3D プリンタで作成した翼端板模型

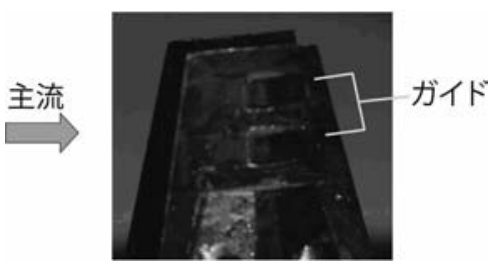

第 8 図 テーパ型複葉翼模型の翼端部拡大図

で用いる翼端は翼厚約 $1 \mathrm{~mm}$ と薄く, 翼端板の取り付けに はネジ等で固定することが困難である。また実験中取り外 し可能となるよう，接着剤等での固定は避ける必要があっ た。そこで設計段階で $3 \mathrm{D}$ プリンタを用いて具体的に翼端 板固定部と翼端板形状を製作して検討した。第 6 図に本プ リンタの外観を示す。この装置はパウダーを約 $0.1 \mathrm{~mm}$ ず つ積層し, バインダで固めることで 3 次元造形を行うこと ができる。造形は造形へッドで行われ，造形可能なサイズ は $254 \mathrm{~mm} \times 381 \mathrm{~mm} \times 203 \mathrm{~mm}$ である．製作形状は PC から 3 次元デザインファイル（本研究では STL ファイルを 利用）を入力して決定した。第 7 図は $3 \mathrm{D}$ プリンタで製作 した翼端板を示す。このように風洞実験模型を製作する前 に，本プリンタで作成した実物大模型を通じて形状を検討 することで，設計の失敗が低減される。また模型加工業者 とも加工可能な形状や精度について細かく詰めることがで き，模型設計段階における本プリンタの利用は有効な手段 である。

第 8 図は 3D プリンタで検討後，実際に製作した翼端板を 取り付ける翼端外側の拡大図を示す。また第 9 図は実際に 製作した翼端板を，第 10 図は翼端板をテーパ翼模型に取り 付けた状態を示す。翼模型の翼端外側には第 8 図で示すガ イド（幅 $3 \mathrm{~mm}$ ，高さ $1.3 \mathrm{~mm}$ ）が二つあり，翼端板を上流 側からスライドさせて翼模型に取り付ける。第 9 図に示す 実験で用いた三つの翼端板は以下のとおりである：(a) 翼端

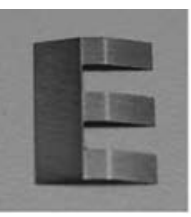

(a) type- $\mathrm{N}$

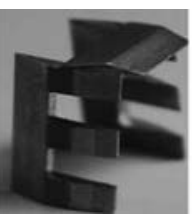

(b) type-A

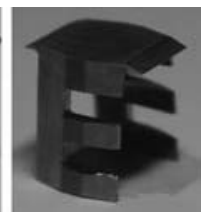

(c) type-B
第 9 図 翼端部模型

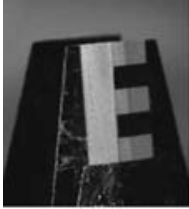

(a) type- $\mathrm{N}$

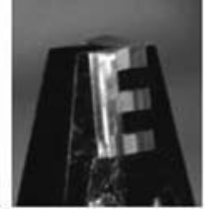

(b) type-A

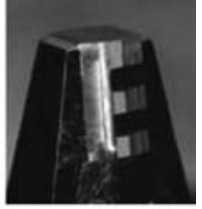

(c) type-B
第 10 図 翼端板取り付け時のテーパ型複葉翼模型

は閉じず，翼外側のガイドに差し込む部分のみ他の翼端板 と同じ形状 (type-N); (b) 翼端板は翼端の翼弦長 $50 \%$ から $100 \%$ 位置を閉じた形状 (type-A); (c) 翼端全体を閉じた形 状 (type-B). なお翼端板の前縁には製作の都合上 $0.2 \mathrm{~mm}$ の厚みをつけた。

2.3 模型荷重および強度計算 風洞始動時と整定時の 二つに分けて荷重計算を行った。風洞始動時の始動荷重は Pope らが示した始動荷重係数の補正值 ${ }^{16)}$ を用いて計算し た。計算条件として，力が発生する面の面積を円盤の面積 $S=32,400 \mathrm{~mm}^{2}$, 比熱比 $\gamma$ を 1.4 とした. 一方, 風洞整 定時の荷重は CFD 解析から模型にかかる荷重を算出した. その結果 $M_{\infty}=1.9$ の風洞始動時に本模型の円盤垂直方 向に $1,394 \mathrm{~N}$ の最大荷重がかかることを確認した.

次にこの最大荷重を用いて模型およびスティングの強度 計算を行った。強度計算では模型円盤の先端に最大荷重が かかったと想定し，スティングの風洞側付け根に発生する最 大応力を算出した。モーメント算出には最大荷重 $1,394 \mathrm{~N}$, スティング風洞側の付け根から模型先端までの距離 $0.452 \mathrm{~m}$ を用いた。得られたモーメントとスティングの断面係数か ら算出したスティングの風洞側付け根に発生する最大応力 $\sigma_{\text {max }}$ は最終的に $67 \mathrm{MPa}$ となった。これに対して SUS304 の降伏応力 $\sigma_{Y}$ は $280 \mathrm{MPa}$ であり, 約 4 倍の安全率で風 洞実験を行った。なおスティングの正確な材料は特定でき なかったがステンレス系材料であるため，ここでは代表的 な SUS304の降伏応力 $\sigma_{Y}$ と比較した.

2.4 PSP 計測手法 PSP 計測手法 ${ }^{13,14)}$ を用いて複葉 翼の翼面圧力分布を計測した. PSP で用いる色素は, 励起 光が照射されるとエネルギーを与えられ，そのエネルギー を蛍光や燐光といった発光で失い, 基底状態に戻る. 一方, まわりの酸素分子と反応しても励起エネルギーは失われ，こ の場合発光は生じない。酸素濃度は分圧に比例し, 空気中 の酸素モル分率 $(=0.21)$ は常に等しいので，この性質に より局所的な酸素濃度と各点の圧力が対応付けられる。こ の原理により PSP の発光強度を測定することで表面圧力 を求めることができる. 

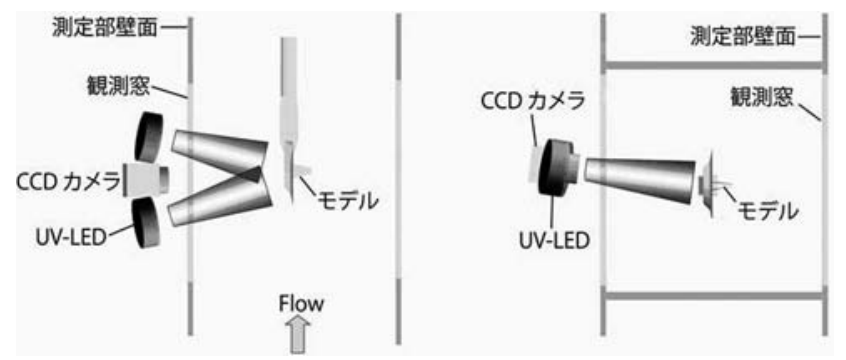

第 11 図 感圧塗料計測光学系（右図では流れ方向は紙面垂直方向）

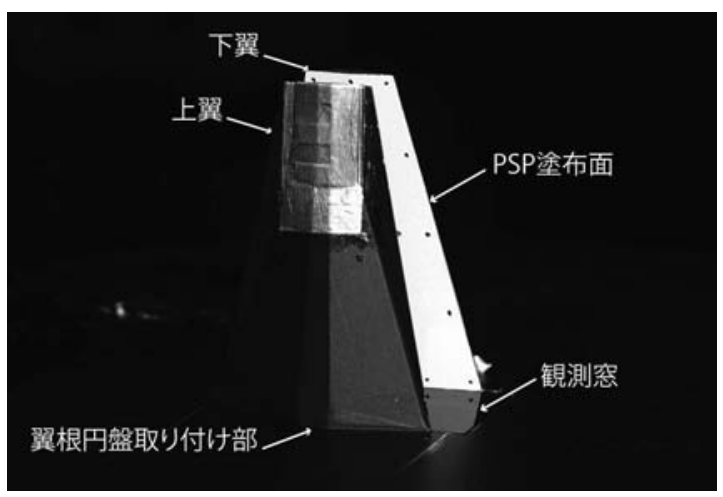

第12図 PSP を塗布した翼模型

本実験では PSP として，ISSI 社（Innovative Scientific Solutions. Inc.) ${ }^{17)}$ のUF470 を用いた.これは感圧色素と してPtTFPP, バインダとして FIB を用いている. 励起波 長は $405 \mathrm{~nm}$ で，発光波長は $650 \mathrm{~nm}$ である.PSP の発光 強度の圧力への変換は, 無風時と通風時画像に対してダー ク減算および位置補正を施し, Stern-Volmer 関係式に従っ た. 本関係式中の較正係数の算出には a priori 法を用い, サ ンプル試験から得られた係数を使用した。ここで注意する 点として, a priori 法を用いる場合, 温度による発光強度变 化を考慮し, 補正する必要がある。本解析では山下ら 18)の 方法に従い, 通風停止直後の無風時画像を基準画像とする ことで温度補正係数が模型全体で一様であると仮定し, 模 型に取り付けた熱電対の温度で補正を行った。

第 11 図は本実験で用いた PSP 計測光学系セットアップ を示す，本実験では狭い翼間に十分な励起光を照射する必 要があるため，2 基の UV-LED（ピーク波長 $395 \mathrm{~nm}$ ） ユ ニットを用いた．LED の前方には $400 \pm 50 \mathrm{~nm}$ のバンド パスフィルタを設置し必要波長のみ通過させている. 発光 強度画像は, $\mathrm{A} / \mathrm{D}$ 分解能 $12 \mathrm{bit}$ の素子冷却型 CCD カメラ (浜松ホトニクス, C4742-80-12AG) を用いた。空間分解 能は $1,344 \times 1,024$ ピクセルである. CCD カメラレンズの 前には発光波長のみを検出するために, $650 \pm 20 \mathrm{~nm}$ の範 囲を透過させるバンドパスフィルタを設置した. カメラレ ンズは $50 \mathrm{~mm}$ を用いた。なお本実験ではテーパ型複葉翼 の下翼上面にPSP を塗布し，向かい合う上翼下側面は光 の反射を防ぐため黒塗料を塗布した。第 12 図はPSP を塗 布してセットアップされたテーパ型複葉翼を示す。また第 2 表に風洞実験条件をまとめて示す.

\begin{tabular}{ccccc}
\multicolumn{5}{c}{ 第 2 表 } \\
\hline Case & 風洞実験条件 \\
\hline 1 & 翼端板 & $M_{\infty}$ & $P_{0}[\mathrm{kPa}]$ & $P_{s}[\mathrm{kPa}]$ \\
2 & type-N & 1.5 & 200.3 & 53.8 \\
3 & type-N & 1.6 & 200.1 & 46.4 \\
4 & type-N & 1.7 & 200.1 & 40.3 \\
5 & type-N & 1.8 & 200.1 & 34.6 \\
6 & type-N & 1.9 & 200.3 & 29.7 \\
7 & type-A & 1.7 & 200.3 & 40.3 \\
8 & type-A & 1.9 & 200.3 & 29.7 \\
9 & type-B & 1.7 & 200.4 & 40.0 \\
\hline
\end{tabular}

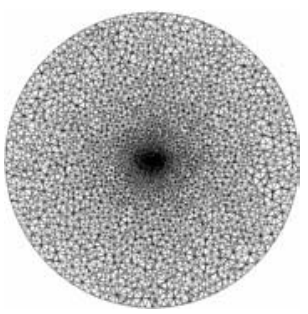

(a) 全体図

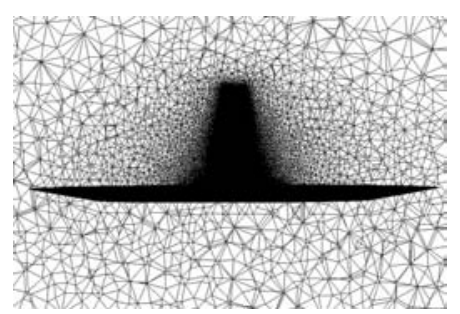

(b) 物体近傍

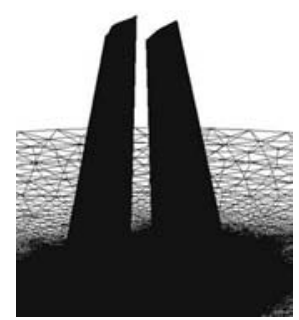

(c) 翼近傍

第13 図 type-N の計算格子

\section{3. 数值解析手 法}

風洞実験条件よりも細かなマッハ数におけるテーパ型超 音速複葉翼の始動特性と空力特性を調べ，翼端板効果を明ら かにするため数值解析を行った。本研究では CATIA Version 5 (DASSAULT SYSTEMS) 19) で計算対象形状を作 製し, 非構造格子生成ツールであるEdge Editor ${ }^{20,21)}$ を用 いて計算格子を作製した. 次に 3 次元非構造格子流体解析 ソルバーの TAS code (Tohoku University Aerodynamic Simulation code) ${ }^{22)}$ を用いて, 本実験模型に対して 3 次元 非粘性準定常計算を行った。ここで準定常計算とは，加速状 態を模擬した解析を行うために, 解析条件とするマッハ数よ り低いマッハ数での定常計算結果を初期值として利用した, 逐次的定常計算を意味する. 支配方程式は 3 次元圧縮性 $\mathrm{Eu}-$ ler 方程式であり，非構造格子上でセル節点有限体積法を用 いて離散化した，対流項における流速の評価には HLLEW 法を用いた。時間積分には計算時間を大幅に短縮するた めに非構造格子用に拡張されたLU-SGS 陰解法を適用した。

第 13 図には例として解析で用いた type-N の非構造格 子を示す．格子点数を減らし計算時間を短くするため，第 4 図と比べ円盤形状は単純化してある。ただし翼周りの流 れに影響が大きい円盤外周の角度および円盤の直径は風洞 実験模型と同様にした。計算対象とした翼模型は type-N, type-A および type-B の 3 種類である。いずれも格子点数 


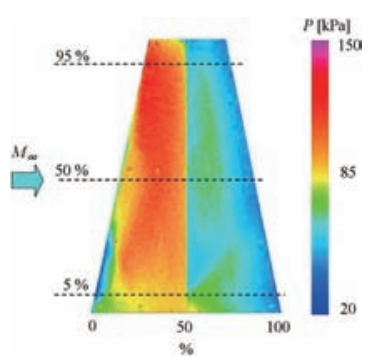

(a) 翼表面圧力分布

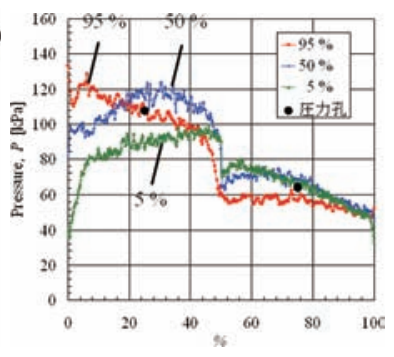

(b) 翼弦方向圧力分布
第14図 PSP 計測結果 (type-N, $\left.M_{\infty}=1.7\right)$

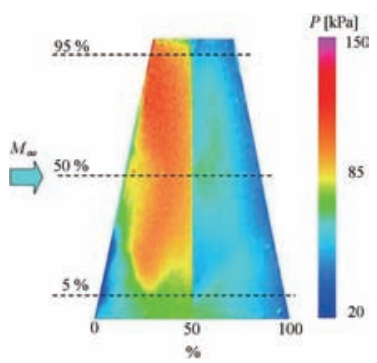

(a) 翼表面圧力分布

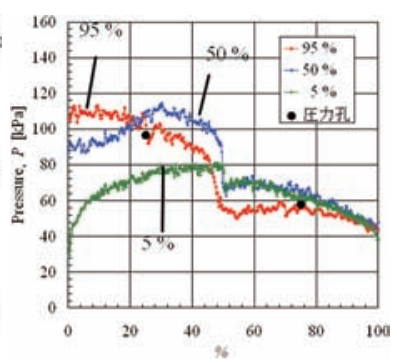

(b) 翼弦方向圧力分布

第 15 図 PSP 計測結果（type-N, $M_{\infty}=1.8 ）$

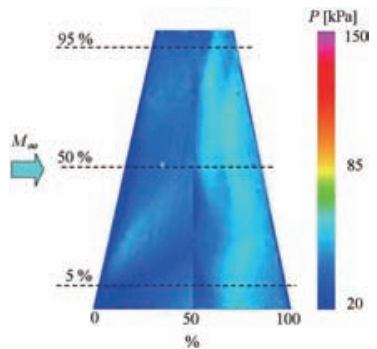

(a) 翼表面圧力分布

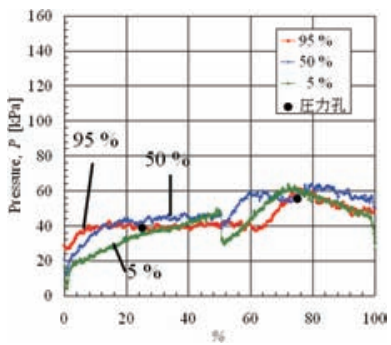

(b) 翼弦方向圧力分布
第 16 図 PSP 計測結果 (type-N, $\left.M_{\infty}=1.9\right)$

は約 1 千万点である.

\section{PSP 計測結果}

第 14 図から第 20 図にPSP 計測で得られた翼表面圧力 分布と翼幅方向 5\%, $50 \%$ 拉よび $95 \%$ 位置の翼弦方向圧力 分布を図示する.第 14 図から第 16 図は type-N の $M_{\infty}=$ $1.7,1.8,1.9$; 第 17 図と第 18 図は type-A 模型の $M_{\infty}=$ 1.7 と 1.9 ; 第 19 図と第 20 図は type-B の $M_{\infty}=1.7$ と 1.9 の結果である. 各図 (b) には, 翼幅方向 $50 \%$ 位置に設 けた静圧孔の計測值を黒丸で合わせて示す。いずれのケー スに扔いても50\%位置の PSP 計測值と静圧孔の值は概ね 一致しており, PSP 計測結果の妥当性が確認できる。

第 14 図から第 16 図より, マッ八数の増加に伴い翼弦方 向 $0 \%$ から $50 \%$ 位置の翼表面圧力が低くなることがわかる. これは $M_{\infty}=1.7$ と 1.8 ではテーパ翼間の流れがチョーク して不始動状態にあるが，マッ八数の増加とともに翼根前 縁から低圧領域が広がり, $M_{\infty}=1.9$ の始動状態へ移行し ていくからである. $M_{\infty}=1.9$ の始動状態では, テーパ翼

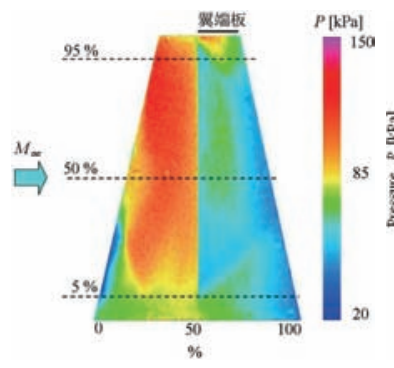

(a) 翼表面圧力分布

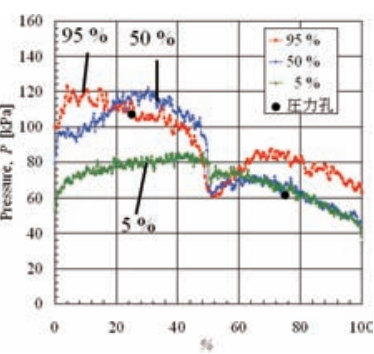

(b) 翼弦方向圧力分布
第 17 図 PSP 計測結果 $\left(\right.$ type-A, $\left.M_{\infty}=1.7\right)$

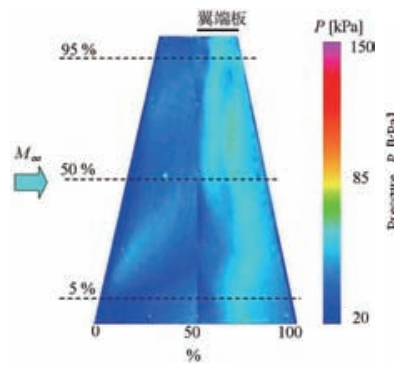

(a) 翼表面圧力分布

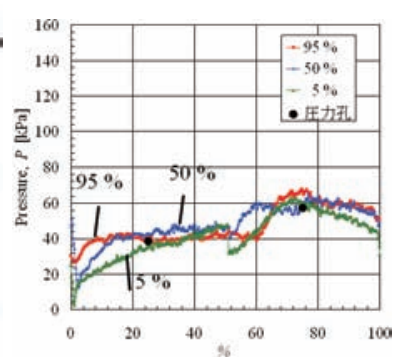

(b) 翼弦方向圧力分布
第 18 図 PSP 計測結果（type-A， $M_{\infty}=1.9 ）$

型の理想的な衝撃波干渉状態に近づくため，翼弦方向の圧 力分布が平坦な分布に近づくことがわかる.

次に設計マッ八数 $M_{\infty}=1.7$ において翼端板が始動特性 に及ぼす影響を考察する。第 14 図, 第 17 図および第 19 図 に示す type-N, type-A および type-B の結果から, 翼根か ら翼幅方向 50\%位置までは三つの模型に大きな違いは見ら れず，いずれの模型も不始動状態にある。一方，翼端近傍 では type-N に比べて type-A と type-B は圧力が上昇して いる.とくに第 14 図 (b), 第 17 図 (b) 挍よび第 19 図 (b) の $95 \%$ 位置に着目すると, 圧力上昇の様子がよく見てとれ る. type-A では翼端板から発生する衝撃波によって翼弦方 向 50\%から 100\%位置で圧力が上昇しており, type-B は翼 端板により翼間の高圧領域と主流静圧の差から生じる翼端 からの流出が妨げられ, 翼間流れの 2 次元性が高まるため に翼弦方向全体にわたり圧力が上昇していることがわかる.

同様に非設計点 $M_{\infty}=1.9$ における翼端板の影響を調 べる. 第 16 図, 第 18 図の結果から, type- $\mathrm{N}$ と type-A で は翼間流れは始動状態にあることがわかる。一方, 第 20 図 から type-B は不始動状態であることがわかる。これは翼 端板により, 翼端からの流出が妨げられ, 始動状態へ移行 できなかったためだと考えられる. type-A は始動状態にあ るため, 前縁から $50 \%$ 位置の翼端部で起こる流出が不始動 状態から始動状態への移行に大きな影響をもつといえる.

\section{CFD解析結果}

翼端板がテーパ型複葉翼にもたらす空力特性の变化とそ の原因を, CFD 解析結果を基に議論する。第 3 表は CFD 解析より得られた, 本実験模型のマッ八数に対する抗力係 数 $\left(C_{d}\right)$ を示す.この $C_{d}$ 值は翼端板を含む值であり円盤 


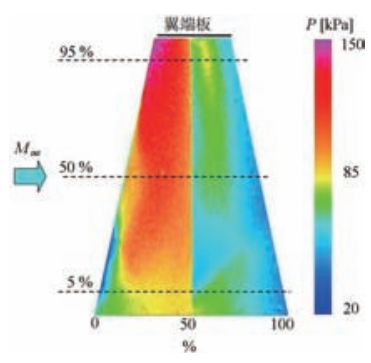

(a) 翼表面圧力分布

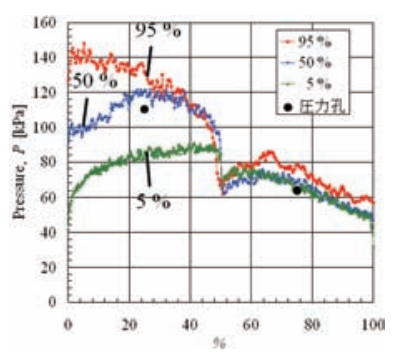

(b) 翼弦方向圧力分布
第 19 図 PSP 計測結果 (type-B, $\left.M_{\infty}=1.7\right)$

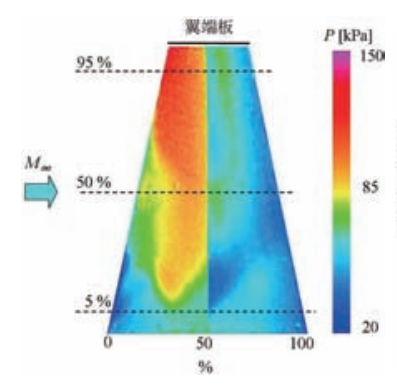

(a) 翼表面圧力分布

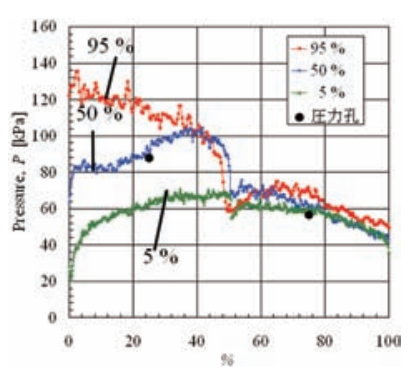

(b) 翼弦方向圧力分布
第 20 図 PSP 計測結果 (type-B, $M_{\infty}=1.9$ )

\begin{tabular}{|c|c|c|c|}
\hline マッハ数 $M_{\infty}$ & type-N & type-A & type-B \\
\hline 1.5 & 0.2241 & 0.2252 & 0.2271 \\
\hline 1.6 & 0.2126 & 0.2135 & 0.2160 \\
\hline 1.7 & 0.2009 & 0.2016 & 0.2052 \\
\hline 1.8 & 0.1823 & 0.1824 & 0.1924 \\
\hline 1.803 & 0.1793 & 0.1800 & - \\
\hline 1.81 & 0.1181 & 0.1229 & - \\
\hline 1.82 & 0.1176 & 0.1224 & 0.1888 \\
\hline 1.84 & 0.1167 & - & 0.1840 \\
\hline 1.845 & - & - & 0.1816 \\
\hline 1.85 & - & - & 0.1800 \\
\hline 1.86 & - & - & 0.1202 \\
\hline 1.9 & 0.1144 & 0.1190 & 0.1186 \\
\hline
\end{tabular}

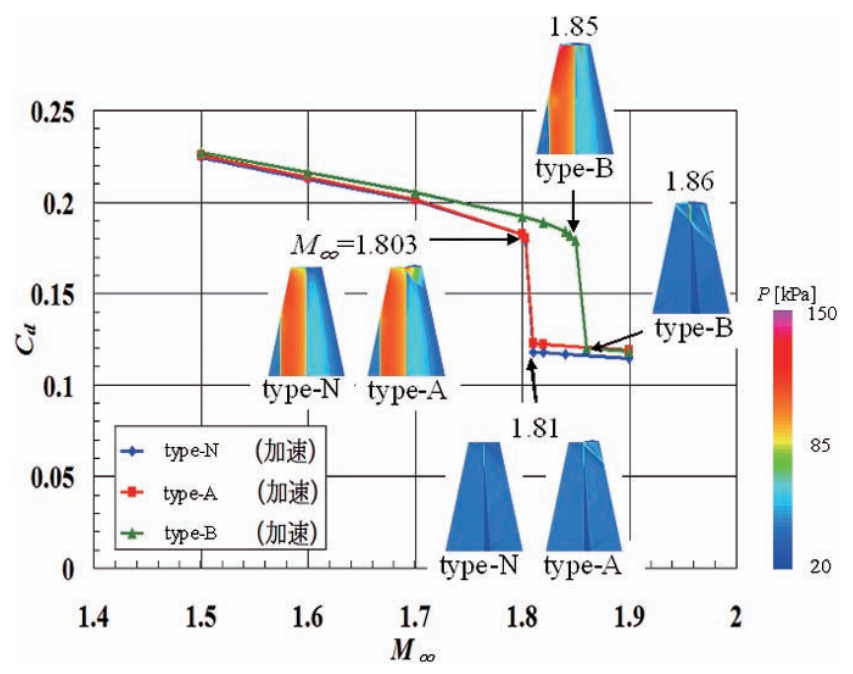

第 21 図 各翼模型のマッハ数に対する $C_{d}$ 值と翼表面圧力分布

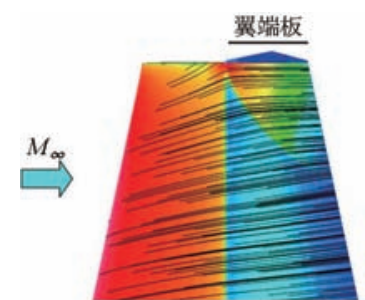

(a) $M_{\infty}=1.7$

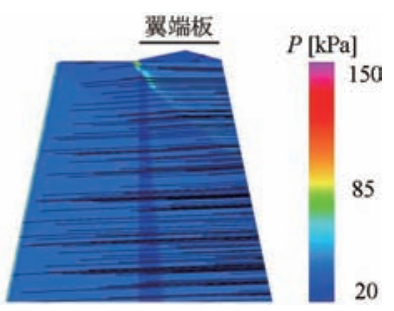

(b) $M_{\infty}=1.9$
第 22 図 CFD 計算による type-A の翼表面圧力分布と翼表面の流れ (翼端拡大図)

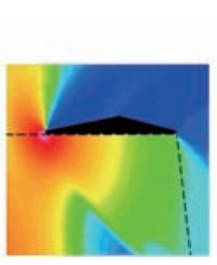

(b) 翼間 $25 \%$ 断面 (c) 翼面近傍断面

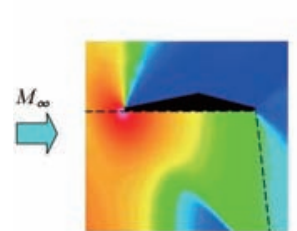

(a) 翼間 $50 \%$ 断面

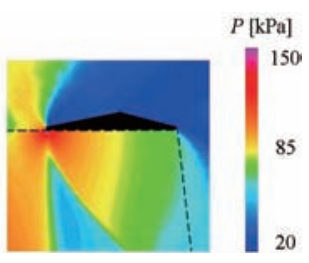

0

第 23 図 翼端板（type-A）周りの空間圧力分布 $\left(M_{\infty}=1.7\right)$

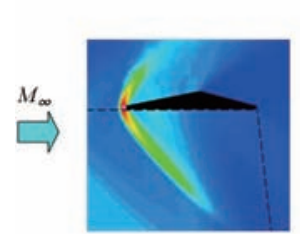

(a) 翼間 50\%断面 (b) 翼間 25\%断面 (c) 翼面近傍断面
$P[\mathrm{kPa}]$
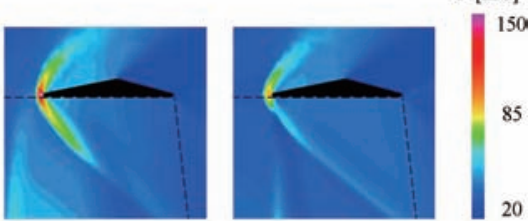

20
第 24 図 翼端板（type-A）周りの空間圧力分布 $\left(M_{\infty}=1.9\right)$

部は含んでいない. 第 21 図には第 3 表の值をグラフで示 すとともに, CFD 解析から得られた各翼模型の翼表面圧力 分布を合わせて示す。第 21 図より, type- $\mathrm{N}$ と type-A は $M_{\infty}=1.803$ から $M_{\infty}=1.81$ の間で抵抗值が大幅に減少 している. 過去の研究で, 流れが不始動状態から始動状態 へと移行する際，造波抵抗值の大幅な減少に伴う抵抗值の 不連続特性が確認されている5). 従って type-N と type-A はこれら同様のマッ八数領域で流れが始動したと判断でき る. 一方, type-B は $M_{\infty}=1.85$ から $M_{\infty}=1.86$ の間で 流れが始動し, type-N 拉よび type-A と比較して始動マッ 八数が 0.05 大きくなる.

第 3 表から type- $\mathrm{N}$ と type-A の $C_{d}$ 值を比較すると, 始 動時では type-A は type- $\mathrm{N}$ に対して約 0.005 大きいが，不 始動時では 0.001 程度しか差が見られない. 始動時に比心゙ て不始動時の $C_{d}$ 值の差が小さくなる理由を議論するため に, 第 22 図に CFD 解析で得られた type- $\mathrm{A}$ 翼端部の $M_{\infty}$ $=1.7$ と 1.9 に拈的翼表面圧力分布と翼表面流れを示す. この結果から, $M_{\infty}=1.7$ の不始動時は翼端部で強い横流 れが生じて, 流れが翼端板の前縁部に角度をもってあたる ことで, 翼端板前縁から衝撃波が発生していることがわか る.この衝撃波が翼面の下流側にあたり高圧領域を形成し， これが推力方向の力として働くことで翼端板による抵抗増 加を抑制していることがわかる。一方， $M_{\infty}=1.9$ の始動 時では翼端部の横流れは小さく, 流れは翼端板に対して主 
流方向に近い角度であたることがわかる。

加えて第 23 図と第 24 図には $M_{\infty}=1.7$ と $M_{\infty}=1.9$ における type-A の翼端板周りの空間圧力断面図を示す： (a) $50 \%$ 断面（翼間中央); (b) 25\%断面；(c) 翼面近傍断 面である。いずれの図も破線は翼の外形を表しており，黒 の三角形が翼端板の断面を表す。また各図の上側が翼端外 側方向, 下側が翼根方向である. 翼端板の外側表面に着目 すると, $M_{\infty}=1.7$ と 1.9 では翼端板の圧力分布が異なる ことがわかる. $M_{\infty}=1.9$ では主流が翼端板にあたり，翼 端板の上流側で圧縮波が発生することで高圧領域が形成さ れる。一方, 翼端板の下流側では膨張波が発生し, 上流側 に比べ低圧領域が形成されている。この上流と下流の圧力 差が生じることで, 翼端板は大きな抵抗を生み出している. これに対して $M_{\infty}=1.7$ では上流側と下流側で圧力の差 が小さい.これは先に述べたが， $M_{\infty}=1.7$ では横流れの 影響から流れが角度をもって翼端板にあたることで, 翼端 板先端の外側から膨張波が生じ, 翼端板上流側の圧力が低 くなる.このため翼端板による抵抗の増加が低く抑えられ ている. 今後, 翼端板の厚みや形状を工夫することで, 不 始動時において翼端板自身の抵抗を低く抑え, さらに翼端 板先端から発生する衝撃波を翼面の下流側にあてることで, type-N に近い抵抗值をとることが可能であるといえる.

最後に第 21 図の CFD 解析結果と, 第 14 図から第 20 図に示す PSP 計測結果の比較を行う。始動マッハ数に関 して, 第 15 図と第 16 図の PSP 計測結果から type-N は $M_{\infty}=1.8$ と 1.9 の間で始動しており, これは第 21 図の type-N の CFD 解析結果と一致する. type-A についても 第 17 図の $M_{\infty}=1.7$ では不始動状態であるが，第 18 図 の $M_{\infty}=1.9$ では始動しており, 第 21 図の CFD 解析結 果とよい一致を示している。しかし type-B の $M_{\infty}=1.9$ において, 第 20 図の PSP 計測結果は不始動状態であるが, 第 21 図の CFD 解析結果では始動状態であった。この始動 マッハ数の不一致の要因としては以下 2 点が考えられる. 一つ目は 2.2 節で述べたように, 模型の加工精度に伴う䛊 差と模型の取り付け誤差である. 第 5 図に示したが, 実験 時の模型の翼間距離は設計值よりも狭く取り付けられてい た. CFD 解析は設計寸法で格子生成された対象に対して 実施されており, 実験模型は CFD 解析よりも翼間距離が 狭いために始動状態への移行が遅れた可能性がある。しか し，実験時の模型の詳細形状を第 5 図に記載したノギス計 測結果のみから再現することは困難である，例えば，翼間 内部の湾曲がある場合にはノギス以外の計測手法を用いる 必要がある. 今後は CFD 解析の形状と実験時の模型形状 との差異が計測結果に及ぼす影響を議論できるよう, 実験 時の模型形状の計測手法も検討する必要がある。二つ目は 境界層の影響である。CFD 解析は非粘性 Euler 計算を実 施しており，翼面に発達する境界層の影響を考慮していな い. 現実の流れでは模型表面に境界層が形成され，翼の厚 みが増す効果をもたらし，また翼の前縁厚みが増すことで 翼前縁から発生する衝撃波の角度が増え, 始動状態への移 行が遅れることが考えられる。
また各翼模型の始動および不始動状態の翼表面圧力分布 を比較すると，両結果でよい一致を示していることがわか る.すなわち第 21 図の CFD 解析結果から, いずれの模型 においても不始動状態では流れのチョーク現象によって翼弦 方向 $0 \%$ から $50 \%$ 位置の翼表面圧力は高まり, 一方始動状 態では翼表面の圧力分布が平坦な分布に近づいている。ま た type-A および type-B 各々の翼端板効果によって, 翼表 面に形成される高圧領域を確認できる。以上の結果は CFD 解析結果を用いた本節の議論について妥当性を保証するも のである。

\section{6. ま と め}

本研究では PSP 計測と CFD 解析を併用して, テーパ型 超音速複葉翼の始動特性および翼端板がテーパ翼の始動特 性と空力特性に及ぼす影響を調べた. PSP 計測と CFD 解 析の結果を統合して得られた結果を以下にまとめる.

・翼端板なしのテーパ型複葉翼 type- $\mathrm{N}$ は翼根側から始動 状態へ移行し, $M_{\infty}=1.803$ から $M_{\infty}=1.81$ の間で 始動する。また type- $\mathrm{N}$ と翼端の $50 \%$ から $100 \%$ を閉じ た type-A は始動マッハ数に大きな違いはない.

・翼端全体を閉じた type-B は， $M_{\infty}=1.85$ から $M_{\infty}=$ 1.86 の間で流れが始動し, type- $\mathrm{N}$ および type-A と比 較して始動マッハ数が 0.05 大きくなる. type-A は翼端 板なしと近いマッハ数で始動したことから, 翼端の前縁 0\%から $50 \%$ 位置で生じる流出が始動・不始動状態の移 行に大きな影響をもつ。

・始動時は type-A の $C_{d}$ 值が type-N より約 0.005 大き くなるのに対して, 不始動時は type-A が約 0.001 大き い程度である．翼端板の効果によって始動時よりも不始 動時で $C_{d}$ 值の差が小さくなる.

本実験の実施にあたり多大なる技術的支援をいただきま した東北大学 小川俊広技官, 奥泉寛之技官, 萩原真澄氏, 金山靖信氏，磯部祐一氏に心より謝意を申し上げます。

\section{参 考 文 献}

1) Liepmann, H. W. and Roshko, A.: Elements of Gas Dynamics, John Wiley \& Sons, Inc., New York, 1957, pp. 107-123.

2) Kusunose, K., Matsushima, K., Goto, Y., Yamashita, H., Yonezawa, M., Maruyama, D. and Nakano, T.: A Fundamental Study for the Development of Boomless Supersonic Transport Aircraft, AIAA Paper 2006-0654, 2006.

3) Kusunose, K., Matsushima, K., Obayashi, S., Furukawa, T., Kuratani, N., Goto, Y., Maruyama, D., Yamashita, H. and Yonezawa, M.: Aerodynamic Design of Supersonic Biplane: Cutting Edge and Related Topics, The 21st Century COE Program International COE of Flow Dynamics Lecture Series, Vol. 5, Tohoku University Press, Sendai, 2007.

4) 藤園 崇, 大山創史, 永井大樹, 大林 茂, 浅井圭介：超音速複 葉翼の始動過程に対する 3 次元性の影響, 日本航空宇宙学会北部 支部講演会, 2009, pp. 52-57.

5) Yamashita, H., Obayashi, S. and Kusunose, K.: Reduction of Drag Penalty by Means of Plain Flaps in the Boomless Busemann Biplane, Int. J. Emerging Multidisciplinary Fluid Sci., 1 (2009), pp. 141-164.

6) Maruyama, D., Matsushima, K., Kusunose, K. and Nakahashi, K.: Aerodynamic Design of Three-Dimensional 
Low Wave-Drag Biplane Using Inverse Problem Method, AIAA Paper 2008-289, 2008.

7) Kuratani, N., Ogawa, T., Yamashita, H., Yonezawa, M. and Obayashi, S.: Experimental and Computational Fluid Dynamics around Supersonic Biplane for Sonic-Boom Reduction, AIAA Paper 2007-3674, 13th AIAA/CEAS Aeroacoustics Conference, Rome, Italy, 2007.

8) Kuratani, N., Yonezawa, M., Yamashita, H., Ozaki, S., Ogawa, T. and Obayashi, S.: Wing Configuration Effects on Flow Field and Aerodynamic Performance of Supersonic Biplane for Sonic-Boom Reduction, ICAS2008-2.4 ST, 26th International Council of the Aeronautical Sciences, Anchorage, U.S.A., 2008, pp. 1-10.

9) Oyama, S., Nagai, H., Ogawa, T. and Asai, K.: Experimental Study on Three-Dimensional Shock Interference Flow of a Supersonic Busemann Biplane, 2008 KSAS-JSASS Joint Symposium on 87 Aerospace Engineering, Jeju, Korea, 2008.

10) Yonezawa, M. and Obayashi, S.: Reducing Drag Penalty in the Three-Dimensional Supersonic Biplane, Proc. Inst. Mech. Eng., Part G: J. Aerospace Eng., 223 (2009), pp. 891-899.

11) 楠瀬一洋, 松島紀佐, 後藤悠一郎, 丸山大悟, 山下 博, 米澤誠 仁: 衝撃波の相殺効果を利用した複葉超音速翼型の研究, 日本航 空宇宙学会論文集，55 (2007), pp. 1-7.

12) 米澤誠仁, 大林 茂: CFD 解析による有限幅の超音速複葉翼の
空力特性評価, 日本航空宇宙学会論文集, 57 (2009), pp. 32-38.

13) Liu, T. and Sullivan, J. P.: Pressure and Temperature Sensitive Paints, Springer, Berlin, Heidelberg, New York, 2004.

14）浅井圭介：感圧塗料による圧力分布の計測技術, 可視化情報, 18 (1998), pp. 97-103.

15) ZCORPORATION, https://zcentral.zcorp.com/

16) Pope, A. and Goin, K. L.: High-Speed Wind Tunnel Testing, Wiley, New York, 1965, pp. 365-369.

17) ISSI, http://www.innssi.com/

18) Yamashita, T., Sugiura, H., Nagai, H., Asai, K. and Ishida, K.: Pressure-Sensitive Paint Measurement of the Flow around a Simplified Car Model, J. Visualization, 10 (2007), pp. 289-298.

19) CATIA: Version 5.10, Dassault Systems 1994-2002.

20) Ito, Y. and Nakahashi, K.: Direct Surface Triangulation Using Stereolithography Data, AIAA J., 40 (2002), pp. 490496.

21) Ito, Y. and Nakahashi, K.: Surface Triangulation for Polygonal Models Based on CAD Data, Int. J. Numerical Methods Fluids, 39 (2002), pp. 75-96.

22) Nakahashi, K., Ito, Y. and Togashi, F.: Some Challenge of Realistic Flow Simulations by Unstructured Grid CFD, Int. J. Numerical Methods Fluids, 43 (2003), pp. 769-783. 